\title{
The Impact of Property Tax on the Development of Real Estate Industry
}

\author{
Ruoke Hu${ }^{*}$, Fangke $\mathrm{Li}^{2}$ \\ ${ }^{1}$ Wuhan Institute of Technology, China \\ ${ }^{2}$ Xi'an University of Posts and Telecommunications, China \\ *Corresponding author: Ruoke Hu, 1181126208@163.com
}

\begin{abstract}
In recent years, due to the rapid development of the real estate industry in China, land speculation has begun in addition to the significant growth in economy. However, this rapid development has led to an extreme rise in housing prices, largely owing to high property tax. This article analyzed the impact of property tax on the development of real estate industry and provided countermeasures.
\end{abstract}

Keywords: Real estate industry; Economic growth; Property tax; House prices

Publication date: June 2021; Online publication: June 30, 2021

The definition and characteristics of property tax are as following:

(1) Definition of property tax

The real estate tax is a type of property tax levied on the owner of the property according to the tax balance value of the house or the rental income.

(2) Characteristics of property tax

Property tax levy is fixed. The property tax is levied on the owner of the real estate as an immovable property which includes the object itself and its source. In regard to that, property tax is only levied on urban business houses.

The prospects for property tax growth are broad. As housing prices continue to climb up across the country, there is room for property taxes to increase.

Second, the development status of property tax. At present, the real estate in China comprises of many types of taxes. As shown in Figure 1, China's property tax had an increasing trend from 89.407 billion yuan to 284.2 billion yuan in the year 2010 to 2020, respectively. This revealed that China's property tax had increased by 3.2 times within ten years.

\begin{tabular}{c|c|c|c|c|c}
\hline Year & Property tax & $\begin{array}{c}\text { Urban land use } \\
\text { tax }\end{array}$ & Total & $\begin{array}{c}\text { Total tax } \\
\text { revenue }\end{array}$ & $\begin{array}{c}\text { Percentage of property tax } \\
\text { and urban land use tax }\end{array}$ \\
\hline 2010 & 894.07 & 1004.01 & 1898.08 & 73210.79 & 2.59 \\
2011 & 1102.39 & 1222.26 & 2324.65 & 89739.39 & 2.59 \\
2012 & 1372.49 & 1541.71 & 2914.20 & 100614.28 & 2.90 \\
2013 & 1581.5 & 1718.77 & 3300.27 & 110530.70 & 2.99 \\
2014 & 1851.64 & 1992.62 & 3844.26 & 119175.31 & 3.23 \\
2015 & 2050.90 & 2142.04 & 4192.94 & 124922.20 & 3.36 \\
2016 & 2220.91 & 2255.74 & 4476.65 & 130360.73 & 3.43 \\
2017 & 2604.33 & 2360.55 & 4964.88 & 144369.87 & 3.44 \\
\hline
\end{tabular}

Figure 1. 
The current property tax reform system implements the concept of pilot cities by using two municipalities which are Shanghai and Chongqing. They are directly under the central government. In view of different locations and economic developments of the two cities, different schemes have been implemented in the real estate tax pilot project. As shown in Figure 2, the property tax rates in Shanghai are lower and more refined. In addition to that, sufficient time is provided for paying taxes. The purpose of the property tax levied by the two cities is different. In Shanghai, property taxes were levied to curb speculative demands while in Chongqing, they were introduced to curb high-end housing consumptions.

\begin{tabular}{|c|c|c|}
\hline Program & Shanghai & Chongqing \\
\hline $\begin{array}{l}\text { Experiment } \\
\text { scope }\end{array}$ & Whole city & Main urban area \\
\hline $\begin{array}{c}\text { Object of } \\
\text { assessment }\end{array}$ & $\begin{array}{l}\text { The residents of the city who newly purchased two } \\
\text { or more housings, non-residents of the city who } \\
\text { newly purchased commercial housings, high-tech } \\
\text { professionals and residents of more than three years } \\
\text { that have more than two housings. }\end{array}$ & $\begin{array}{l}\text { Single-family commercial housings, newly } \\
\text { purchased commercial housings, newly purchased } \\
\text { high-grade housings, and three people that newly } \\
\text { purchased a second ordinary housing. }\end{array}$ \\
\hline \multirow[t]{2}{*}{ Tax rate } & $0.4 \% \sim 0.6 \%$ & $0.5 \% \sim 1.2 \%$ \\
\hline & $\begin{array}{l}0.4 \% \text { is implemented for prices that are less than } 2 \\
\text { times of the average price and } 0.6 \% \text { is implemented } \\
\text { for prices more than twice the average price. }\end{array}$ & $\begin{array}{l}0.5 \% \text { is implemented in single family, high-grade } \\
\text { housing construction area in which the price is less } \\
\text { than } 3 \text { times the average price, as well as the three } \\
\text { new people who bought a second ordinary housing. } \\
1 \% \text { is implemented to those } 3 \text { to } 4 \text { times the average } \\
\text { price and } 1.2 \% \text { is implemented to those } 4 \text { times or } \\
\text { more the average price. }\end{array}$ \\
\hline Taxation base & $70 \%$ of the trade price & Trade price \\
\hline $\begin{array}{l}\text { Taxation } \\
\text { criterion }\end{array}$ & $\begin{array}{l}\text { Based on the average price of new commodity } \\
\text { housing published last year by the City Bureau of } \\
\text { Statistics. }\end{array}$ & $\begin{array}{l}\text { Based on the average price of new commodity } \\
\text { housing was announced in the last two years by the } \\
\text { Land and Housing Management Department. }\end{array}$ \\
\hline $\begin{array}{c}\text { Tax } \\
\text { preferences }\end{array}$ & $\begin{array}{l}\text { The average apartment is no more than } 60 \text { square } \\
\text { meters and new houses are tax-free. }\end{array}$ & $\begin{array}{l}\text { Pre-pilot single-family commercial housings are } 180 \\
\text { square meters and duty-free. Newly purchased } \\
\text { single-family commercial housings and high-grade } \\
\text { housings are } 100 \text { square meters and duty-free. }\end{array}$ \\
\hline Term of tax & Before December 31 of each year & Every year between October 1 and December 31 \\
\hline Purpose of tax & Curb speculative demands & Curb the demand for high-end housings \\
\hline
\end{tabular}

Figure 2.

Third, the impact of real estate tax on the real estate industry are as the following:

(1) The impact of real estate taxes is on the supply and demand as well as the housing prices. The rise in tax will affect the purchasing cost of a building, hence, house prices will increase. This would reduce the social demand which results in the backlog of capital funds and real estate developers. These funds cannot be utilized and eventually, there would be a reduction in the supply of houses. In view of decreasing demand and supply, a new balance would be created, and housing prices would reach a new stability as well. However, in any case, the long-term rise in housing prices would cause an oversupply and thus, resulting 
in a decline of their prices. Therefore, the amount of property tax has a control over the rise and fall of housing prices, thereby avoid inflation of these prices.

(2) The impact of real estate taxes is also on investors. The collection of real estate taxes would increase the investment costs of real estate investors and raise their investment risks. In this way, investors' speculative behaviors and their demand for real estate would markedly reduce.

\section{Disclosure statement}

The author declares no conflict of interest.

\section{References}

[1] Zhang R, 2020, Research on the impact of real estate tax on the real estate Industry. To Pay Taxes, 31.

[2] Li F, 2020, Research on levying real estate tax. Shanghai Commerce, 05.

[3] Fu X, 2020, Analysis of the impact of real estate tax reform on the real estate market. China's Collective Economy, 16. 